\title{
The G7 of Scientific Academies: meetings and role
}

\author{
Alberto Quadrio Curzio ${ }^{1}$
}

Published online: 6 October 2017

(C) Springer International Publishing AG 2017

Italy in 2017 holds the Group of 7 Presidency. Within the framework of the many political-institutional events and summits, the Accademia Nazionale dei Lincei has organized a meeting of the G7 National Academies. Since 2005, the Lincei Academy has participated in the joint initiatives of the National Academies of the G7-G8 countries. These initiatives were first launched by the Royal Society during the United Kingdom's Presidency of the G8 in 2005. Since 2014, the Meetings have been held as G7, without Russia.

The National Academies meet annually to elaborate Joint Statements on important global issues that are scientifically relevant and require the attention of Governments. The Joint statements are concise (usually not more than 2000 words) in order to deliver clear messages.

The 2017 Meeting was organised in two phases by the Lincei Academy in Rome.

The processing phase, held on 23-24 March 2017, involved scientists appointed by the G7 Academies organized in working groups that prepared the final version of the three Joint Statements, which were originally proposed and drafted by the Lincei Academy. Following the meetings, the statements were officially endorsed in April by the seven Academies and then signed by their Presidents.

The second and conclusive phase was held at the Science Conference "The role of National Academies and International Academy Networks" in advising institutions on the 3rd of May 2017. Speakers at this Conference included the Presidents or Vice Presidents of the G7 Academies of Sciences and of the N7, an acronym which I use to indicate the seven most important international Networks of Academies. Three Joint Statements were released at the Conference on: (1) Cultural heritage: building resilience to natural disasters (Working Group coordinated by Giovanni Seminara, Lincei Academy); (2) The challenge of

Alberto Quadrio Curzio

alberto.quadriocurzio@unicatt.it

1 Università Cattolica, Accademia Nazionale dei Lincei, Milano, Italy 
neurodegenerative diseases in an aging population (Working Group coordinated by Maurizio Brunori, Lincei Academy); (3) New economic growth: the role of science, technology, innovation and infrastructure (Working Group coordinated by Alberto Quadrio-Curzio, Lincei Academy). The Joint Statements can be found on the Lincei website http://www.lincei.it.

Given that this role of National Academies of Sciences in not generally known, I think it would be useful to quote paragraph 3 of the Joint Statement on "New economic growth":

\begin{abstract}
"The Academies of Sciences of G7 countries have an important responsibility in identifying challenges for research and in promoting efficient institutional frameworks to deliver technological solutions for sustainable and inclusive growth. We reaffirm that science is an international endeavor and a collaborative enterprise. The role of Academies as guardians of the values of free inquiry and of the paramount importance of scientific evidence is more critical than ever.

In advising governments on policy, the Academies should take a holistic approach to the problems of sustainable development that enables interdisciplinary research involving the natural, social and human sciences. The Academies are also committed to provide open fora where important developments in science and technology are discussed, with specific attention to their interconnections.

In order to fulfill these tasks, Academies are committed to collaborate-both directly and in international associations - in addressing problems with a major international dimension, in searching for common solutions and in evaluating implications of policy options"
\end{abstract}

This role has been understood and appreciated by the Italian Institutions. In fact, the Joint Statements were presented on the 3rd of May to the Italian Government, represented at the Lincei Academy by the Minister of Cultural Heritage, Dario Franceschini, and the Minister of Economy and Finance, Pier Carlo Padoan. Both Ministers delivered important speeches. The Conference was concluded at the Quirinale Palace where the President of the Italian Republic, Sergio Mattarella, to whom I express my deep gratitude, made a thoughtful and wise speech on science for human progress.

We publish here the speech given by Minister Pier Carlo Padoan on "After the crisis, the meaning of New Growth". The journal is grateful to him for having accepted my proposal of adding to the Joint Statement on "New Growth" the institutional evaluations of the Italian Ministry of Economy and Finance. Minister Padoan is also professor of political economy (on leave) from the University La Sapienza of Rome and has held important positions at the IMF and the OECD. He has always adopted a scientific and political approach to problems of economic growth. 